\title{
INTERVENSI KOMUNITAS SABANGMERAUKE DENGAN COMPETENCY BASED INTERVIEW
}

\section{Penny Handayani ${ }^{1}$, Reneta Kristiani ${ }^{2}$, Naomi Hanalisa ${ }^{3}$, F. Resa Kawatu ${ }^{4}$, Linda Benita ${ }^{5}$, Karina Lois ${ }^{6}$ dan Katherine ${ }^{7}$}

\author{
${ }^{1}$ Fakultas Psikologi UNIKA Atma Jaya Jakarta \\ Email: penny.handayani@atmajaya.ac.id \\ ${ }^{2}$ Fakultas Psikologi UNIKA Atma Jaya Jakarta \\ Email: reneta.kristiani@atmajaya.ac.id \\ ${ }^{3}$ Fakultas Psikologi UNIKA Atma Jaya Jakarta \\ Email: naomi.2016070234@student.atmajaya.ac.id \\ ${ }^{4}$ Fakultas Psikologi UNIKA Atma Jaya Jakarta \\ Email: florentina.2016070110@student.atmajaya.ac.id \\ ${ }^{5}$ Fakultas Psikologi UNIKA Atma Jaya Jakarta \\ Email: linda.2016070195@student.atmajaya.ac.id \\ ${ }^{6}$ Fakultas Psikologi UNIKA Atma Jaya Jakarta \\ Email: karina.2016070165@student.atmajaya.ac.id \\ ${ }^{7}$ Fakultas Psikologi UNIKA Atma Jaya Jakarta \\ (Email: katherine.2016070186@student.atmajaya.ac.id
}

\begin{abstract}
This research aims to explore the issues of volunteer engagement faced by the SabangMerauke Community that affect the level of voluntary self-belonging to the community. This research is a type of descriptive research with a descriptive research method approach. Determination of research subjects using purposive sampling techniques. Based on this technique, the subjects of this study were all administrators and volunteers of the SabangMerauke Community and the participants involved such as the SabangMerauke Brother, Sister and Family. Data collection techniques used were interviews and questionnaires online. Interventions given to the SabangMerauke community are interventions in the process of recruiting volunteers using competency-based interview techniques. The conclusion from the series of interventions provided is that the provision of training for trainers to the SabangMerauke Community is appropriate and targets what they need. This is based on the group's assessment of the success indicator checklist that was designed before the training for trainers took place. Apart from the indicators of success, there is concrete evidence that shows the success of this intervention, namely the response and activeness of the two respondents present. Besides listening, they also asked a number of questions and actively confirmed their knowledge to the group by discussion. The community also asked the group to be able to follow up the community recruitment process the following year. Although in terms of interventions classified as successful, but there are some obstacles experienced by groups such as interventions that can only be done once because it follows the schedule of the community administrator.
\end{abstract}

Keywords: intervention,; volunteer loyalty; recruitment; competency based interviews

\begin{abstract}
ABSTRAK
Penelitian ini bertujuan untuk menggali permasalahan volunteer engagement yang dihadapi Komunitas SabangMerauke yang mempengaruhi tingkat self-belonging relawan terhadap komunitas. Penelitian ini merupakan jenis penelitian deskriptif dengan pendekatan metode penelitian deskriptif. Penentuan subjek penelitian menggunakan teknik purposive sampling. Berdasarkan teknik tersebut, subjek penelitian ini adalah seluruh pengurus dan relawan Komunitas SabangMerauke serta para peserta yang terlibat seperti Kakak, Adik dan Famili SabangMerauke. Teknik pengumpulan data yang digunakan adalah wawancara dan penyebaran kuesioner online. Intervensi yang diberikan untuk komunitas SabangMerauke adalah intervensi dalam proses perekrutan relawan dengan teknik competencybased interview. Kesimpulan dari rangkaian intervensi yang diberikan adalah pemberian training for trainers kepada Komunitas SabangMerauke sudah tepat dan menyasar pada apa yang mereka butuhkan. Hal ini didasari atas penilaian kelompok terhadap checklist indikator keberhasilan yang telah dirancang sebelum training for trainers berlangsung. Selain dari indikator keberhasilan, terdapat bukti nyata yang menunjukkan keberhasilan intervensi ini yaitu respon dan keaktifan dari kedua responden yang hadir. Selain mendengarkan, mereka juga melontarkan beberapa pertanyaan serta secara aktif mengkonfirmasi pengetahuan mereka kepada kelompok dengan berdiskusi. Pihak komunitas juga meminta kelompok untuk dapat menindaklanjuti proses rekrutmen komunitas di tahun
\end{abstract}


berikutnya. Walaupun dari segi intervensi tergolong berhasil, namun terdapat beberapa kendala dialami oleh kelompok seperti intervensi yang hanya dapat dilakukan satu kali karena mengikuti jadwal dari pengurus komunitas.

Kata kunci: intervensi' loyalitas relawan; rekrutmen; wawancara berbasis kompetensi

\section{PENDAHULUAN}

Indonesia dengan budaya yang beragam, sehingga menuntut masyarakatnya untuk hidup bertoleransi antar sesama masyarakat Indonesia. Menurut Abdul Halim (2008), toleransi adalah setara menjadi positif dan mengapresiasi orang lain dengan mementingkan hak hak sebagai manusia (Rahman \& Khambali, 2013). Dilansir dari kompas.com (Siahaan, 2019), bahwa terdapat empat provinsi di Indonesia dengan tingkat toleransi tinggi karena mendapat nilai diatas 8, namun kota lainnya dengan tingkat sedang dan buruk. Nilai toleransi di Indonesia pada tahun 2014 sampai 2017 cenderung meningkat, namun hal tersebut berkebalikan saat memasuki tahun politik. Hal tersebut berkaitan dengan kasus mantan gubernur Jakarta yaitu Basuki Tjahaja Purnama dari kelompok minoritas yang dipidana dalam kasus penodaan agama. Toleransi merupakan hal yang penting karena dengan bertoleransi maka dapat terhindar dari adanya perpecahan antar umat beragama dan dapat mempererat tali silaturahmi. Toleransi penting terutama untuk bangsa Indonesia yang didalamnya terdapat beragam suku bangsa, agama dan bahasa. Toleransi adalah modal utama untuk hidup berdampingan dengan orang sekitar yang memiliki latar belakang berbeda.

Oleh karena itu kelompok memilih komunitas dengan nilai yang menekankan pada toleransi yaitu komunitas SabangMeruake. SabangMerauke adalah komunitas yang bergerak di bidang pendidikan. Komunitas ini menekankan pada pentingnya nilai toleransi antar umat beragama, suku, dan ras. SabangMerauke percaya bahwa toleransi tidak bisa diajarkan hanya dengan lecturing, namun juga harus dilakukan. Oleh karena itu SabangMerauke mendatangkan remaja yang duduk di SMP untuk tinggal bersama dengan keluarga yang ada di Jakarta dan dibimbing dengan seorang dewasa muda yang duduk dibangku perkuliahan. Remaja SMP, dewasa muda, dan keluarga di Jakarta memiliki ras dan agama yang berbeda, sehingga peserta di SabangMerauke merasakan dan belajar mengenai perbedaan tersebut dan memaknai-nya.

Masalah yang dihadapi SabangMerauke adalah loyalitas relawan. Penyebab loyalitas relawan rendah karena karakteristik yang dimiliki oleh relawan tidak sesuai dengan karakteristik yang dibutuhkan oleh Komunitas SabangMerauke. Karakteristik yang dibutuhkan adalah inisiatif, bertanggung jawab, dan cukup mengenal SabangMerauke. Selain itu relawan juga tidak memiliki keterikatan dengan komunitas SabangMerauke, sehingga komunikasi kurang terjalin dengan baik.

Terdapat siklus mengenai volunteer engagement yaitu membantu untuk menciptakan hal tersebut terulang terus menerus dengan beberapa tahap (Snyder \& Omoto, 2018). Tahap pertama adalah needs analysis, yaitu mengetahui apa tujuan dari organisasi, bagaimana volunteer membantu, peran volunteer untuk apa. Pada komunitas SabangMerauke juga melakukan hal ini, dimana sebelum melakukan rekrutmen, komunitas SabangMerauke terdapat rapat kerja untuk menentukan karakteristik relawan yang dicari oleh komunitas. Tahap kedua yaitu recruitment untuk mencari target audiens, hal apa yang menarik bagi mereka, dimana organisasi dapat menemukannya, dan mitra apa yang dapat membantu organisasi terhubung. Komunitas SabangMerauke melakukan tahap recruitment dengan menyebarkan kuisioner online, maka calon relawan diminta untuk mengisi seputar biodata. Tahap ketiga yaitu screening adalah mencakup persyaratan minimum sebagai volunteer, apa motivasi dari setiap kandidat, bagaimana volunteer ingin berkontribusi, dan yang terakhir bagaimana cara memberi penilaian pada calon relawan. 
Komunitas SabangMerauke juga melakukan hal ini untuk menentukan relawan yang akan menjadi bagian dari SabangMerauke.

Tahap yang keempat placement adalah mengenai peran spesifik apa yang akan dilakukan volunteer, komitmen yang harus mereka lakukan, dan orang yang akan membantu mereka serta kapan mereka akan memulai tugas mereka. Tahap kelima adalah orientation atau training kegiatan ini adalah kegiatan yang akan menyambut relawan untuk melayani, keterampilan khusus apa yang mereka butuhkan untuk peran mereka, cara orientasi kebijakan dan prosedur akan terjadi, dan cara pelatihan untuk peran mereka terjadi. Komunitas SabangMerauke melakukan tahap keempat dan kelima dalam satu hari yang sama. Hal tersebut dikarenakan pekerjaan utama sebagian besar relawan SabangMerauke adalah mahasiswa dan karyawan yang sulit untuk menentukan jadwal yang tepat untuk kumpul bersama. Oleh karena itu tahap placement dan training ini dijadikan satu hari yang SabangMerauke sebut adalah induksi.

Tahap keenam resourcing adalah menjelaskan yang relawan akan lakukan dan tidak lakukan, tanggal tanggal penting bagi relawan, bagaimana ketua tim berkomunikasi, bagaimana cara kerja didelegasikan. Pada tahap ini komunitas menjelaskan juga kepada calon relawan mengenai agenda selama kepengurusan berlangsung pada saat hari induksi. Tahap ketujuh recognition adalah bagaimana pemimpin tim memberikan dukungan, dalam hal apa relawan akan diakui, bagaimana mengakui pencapaian tertentu, dan peluang kepemimpinan apa yang akan tersedia. Pada tahap ini ketua divisi atau yang biasa disebut manager divisi tidak melakukannya sekali, namun selama kegiatan divisi berlangsung manager di setiap divisi memberikan dukungan dengan memberikan apresiasi dan dengan memberikan tambahan materi kepada relawan mengenai kegiatan yang akan dilakukan.

Tahap kedelapan adalah retention yaitu bagaimana organisasi menjelaskan mengapa relawan pergi, bagaimana organisasi melacak kepuasan sukarela dari waktu ke waktu, bagaimana organisasi akan melaporkan perubahan program kepada sukarelawan, dan bagaimana organisasi mengumpulkan saran dari sukarelawan. Tahap yang terakhir adalah evaluation. Tahap evaluation menjelaskan tentang bagaimana organisasi mengelola jaminan kualitas yang berkelanjutan, bagaimana organisasi menangani keluhan sukarelawan, bagaimana organisasi menilai dimana kesenjangan program masih ada, dan bagaimana organisasi melacak sasaran program. Pada tahap kedelapan dan terakhir sudah dilakukan SabangMerauke.

Dari kesembilan siklus tersebut SabangMerauke sudah melaksanakannya, namun masih ditemukan masalah terkait rendahnya loyalitas relawan. Setelah ditelusuri berdasarkan siklus tersebut, pada saat recruitment, relawan ditanyakan mengenai biodata. Namun kurang melihat kesungguhan relawan mendaftar. Pada saat tahap ini kurang menggali potensi dari relawan itu sendiri. Oleh karena itu kelompok memilih intervensi di bidang recruitment.

Recruitment merupakan tahap awal untuk menarik sumber daya manusia dalam sebuah organisasi atau komunitas untuk mengisi jabatan atau divisi yang kosong. Tahap ini merupakan tahap yang penting karena kualitas sumber daya manusia merupakan salah satu faktor utama yang menentukan keberhasilan proses dan tujuan sebuah komunitas. Recruitment sendiri merupakan proses pencarian dan pemikatan pelamar yang mampu untuk melamar sebagai karyawan (Handoko, 2008). Agar komunitas SabangMerauke (SM) memiliki relawan yang sesuai dengan kebutuhan komunitas dan kualitas yang baik, maka komunitas harus memiliki proses rekrutmen yang baik juga. Proses recruitment terdiri atas beberapa tahapan seperti identifikasi dan evaluasi sumber-sumber penarikan tenaga kerja, proses seleksi, penempatan dan orientasi tenaga kerja (Potale, Lengkong \& Moniharapon, 2016). 
Lalu kelompok memutuskan untuk menggunakan teknik wawancara untuk melakukan recruitment atau seleksi. Teknik wawancara merupakan teknik seleksi yang baik dan memberikan gambaran yang jelas mengenai calon relawan. Namun, wawancara yang dilakukan oleh Komunitas Sabang Merauke masih kurang mendalam dan terstruktur. Maka dari itu, Competency-Based Interview (CBI) merupakan jenis wawancara yang cocok dan sesuai dengan kebutuhan seleksi di Komunitas SabangMerauke. Competency-Based Interview (CBI) sendiri merupakan bentuk wawancara yang menggunakan behavioral questions untuk membantu pewawancara menguji kandidat berdasarkan kompetensi khusus yang dibutuhkan pada posisi tertentu (Kessler, 2006). Pertanyaan yang diberikan menyasar kepada karakteristik dan pengalaman individu dalam bekerja sebelumnya. Jawaban yang diberikan oleh calon relawan harus didasarkan pada tindakan nyata yang dilakukan sebelumnya dan bukan merupakan tindakan yang 'akan' diambil. Dari hasil performa kerja sebelumnya, diharapkan perilaku dan karakteristik yang sama akan muncul dan memberikan hasil pekerjaan yang baik. Seleksi berdasarkan kompetensi ini muncul dari hipotesis bahwa kekonsistenan antara kebutuhan kerja dan kompetensi kandidat menghasilkan kualitas kerja dan kepuasan kerja yang baik (Caldwell \& O’Reilly, 1990).

Pertanyaan yang akan digunakan untuk tahap seleksi pada Komunitas SabangMerauke menggunakan aspek Spencer. Aspek-aspek berikut merupakan aspek-aspek kompetensi sesuai teori kompetensi kerja yang dikemukakan oleh Spencer dan Spencer (1993). Menurut Lyle M. Spencer dan Signe M. Spencer (1993), kompetensi merupakan bagian dalam dan selamanya ada pada kepribadian seseorang serta dapat memprediksi tingkah laku dan performansi seseorang secara luas pada semua tugas dan situasi. Namun kelompok tidak memakai semua aspek dari dari Spencer. Aspek kompetensi kerja yang dipilih berdasarkan kebutuhan SabangMerauke dari hasil wawancara dan survey yang sudah dilakukan.

Berdasarkan hasil needs assessment ditemukan bahwa terdapat aspek-aspek yang perlu diperbaiki dalam proses seleksi bagi para relawan antara lain kesadaran berorganisasi (organizational awareness), komunikasi (communication), berpikir konseptual (conceptual thinking), serta komitmen (organizational commitment). Hasil dari needs assessment menyatakan bahwa pentingnya peningkatan komunikasi antar relawan terutama dalam satu divisi. Komunikasi (communication) yang perlu ditingkatkan meliputi penyampaian informasi dan pemberian respons sehingga tidak terjadi kesalahpahaman maupun tidak meratanya informasi antar relawan maupun antar divisi. Kesadaran berorganisasi (organizational awareness) ditujukan untuk melihat bagaimana kemampuan para relawan memahami gambaran job-description mereka dalam divisi. Hal ini juga ditujukan untuk menyamakan ekspektasi dan realita relawan terhadap alur kerja komunitas. Aspek berpikir konseptual (conceptual thinking) merujuk pada bagaimana relawan nantinya menyadari, mengidentifikasi, bertindak, dan memberikan solusi terhadap permasalahan yang dialami komunitas. Aspek terakhir yaitu aspek komitmen (organizational commitment) merujuk pada bagaimana relawan menentukan skala prioritas terhadap kepentingan individu dan kepentingan komunitas.

Sesuai dengan masalah loyalitas relawan, maka kelompok bertujuan memberikan intervensi agar Komunitas SabangMerauke mendapatkan relawan yang loyal dengan komunitas SabangMerauke. Tujuan fungsional dari kegiatan ini adalah agar hasil intervensi dapat dimanfaatkan dan digunakan komunitas sebagai referensi dasar untuk mengambil langkah kebijakan terkait masalah loyalitas relawan sehingga komunitas dapat bekerja sesuai timeline dengan hasil akhir optimal. Selain itu, kegiatan diharapkan juga memberikan pengetahuan dan pengalaman kepada komunitas terkait rekrutmen dengan metode wawancara berbasis kompetensi. Manfaat dari kegiatan adalah hasil kegiatan dapat digunakan untuk memberikan 
gambaran akan sistem seleksi relawan dengan metode wawancara berbasis kompetensi. Hasil kegiatan juga dapat dijadikan sarana untuk menyusun strategi terkait masalah loyalitas relawan yang dialami dalam komunitas. Untuk hasil akhirnya, diharapkan agar intervensi yang diberikan dapat mengatasi permasalahan utama yang ada dalam komunitas ini yaitu relawan yang hilang saat program berlangsung. Intervensi ini diharapkan dapat mengurangi persentase jumlah relawan yang hilang dan diharapkan agar meningkatnya jumlah relawan SabangMerauke yang loyal dalam bekerja selama program berlangsung dari tahun sebelumnya.

\section{METODE PELAKSANAAN/METHOD}

Intervensi yang dilakukan merupakan intervensi sistem dalam Komunitas SabangMerauke. Intervensi yang dilakukan adalah memberikan pelatihan tentang competency based interview kepada General Manager dan Badan Pengurus Harian (BPH). Kriteria serta pertanyaan yang telah di desain oleh kelompok nantinya akan dipertimbangkan dan disederhanakan oleh pengurus Komunitas SabangMerauke. Setelah semuanya tersusun, maka BPH melakukan training for trainers (TFT) kepada seluruh kepala divisi.

Pada hari Selasa, 7 Mei 2019, kelompok melaksanakan training for trainers yang dihadiri oleh General Manager (GM) Komunitas SabangMerauke, Reynold Hamdani dan Engagement Manager (EM) yaitu Wildan Mahendra Madani. Training ini dilakukan di sebuah meeting room JSCHIVE by Cohive yang beralamat di Jl. Prof. DR. Satrio No.7, RT.3/RW.3, Karet Kuningan, Kecamatan Setiabudi, Kota Jakarta Selatan, Daerah Khusus Ibukota Jakarta 12950 dari pukul 14.00 hingga pukul 16.10. Peralatan dan fasilitas yang digunakan untuk mendukung jalannya training adalah laptop beserta materi pembelajaran yang tersambung pada sebuah TV, handouts berisikan materi mengenai competency based interview (CBI), hard copy dari tabel pertanyaan yang telah dibuat serta handphone untuk dokumentasi.

Training dimulai tepat waktu sesuai jadwal yang telah dibuat. Seluruh anggota kelompok duduk berhadapan dengan kedua partisipan yang hadir. Pada sesi pertama, seluruh anggota memperkenalkan diri dan pembukaan. Pada sesi pertama, satu anggota kelompok menjelaskan mengenai aktivitas yang akan dilakukan selama training, permasalahan yang ada di Komunitas SabangMerauke, serta intervensi yang akan diberikan. Setelah itu, pada sesi 2, fasilitator menjelaskan mengenai metode panduan pertanyaan competency based interview (CBI) yang disebut 'STAR' (situation, thinking, action dan result). Pada sesi ketiga, fasilitator menjelaskan mengenai "Do" and "Don' $t$ " atau hal-hal yang diperbolehkan dan yang perlu dihindari ketika membuat atau menyampaikan pertanyaan. Setelah mempelajari dasar-dasar competency based interview (CBI) serta cara membuat pertanyaan yang baik dan terbuka, maka kedua partisipan diminta untuk melakukan roleplay kepada dua orang peran pembantu yang seolah-olah ingin mendaftar di Komunitas SabangMerauke. Kedua partisipan diperbolehkan untuk mengikuti panduan wawancara yang telah disediakan dan mengembangkan sendiri pertanyaan dari mereka. Pada setiap peran pembantu diberikan 20 menit untuk melakukan roleplay. Setelah roleplay selesai, kedua partisipan diminta untuk merefleksikan performa mereka serta kesulitan-kesulitan yang mereka hadapi selama roleplay. Kelompok pun juga memberikan feedback kepada kedua partisipan dan mendiskusikannya secara bersama-sama. Di sesi kelima, materi rules of evidence disampaikan dengan memberikan juga contoh jawaban yang codable dan uncodable. Pada sesi keenam, partisipan dijelaskan mengenai cara leveling jawaban interviewee serta mencoba untuk memberikan penilaian terhadap contoh soal yang diberikan. Pada sesi terakhir, fasilitator menjelaskan mengenai benang merah dari keseluruhan training serta penutup. Setelah training selesai, kedua partisipan melontarkan beberapa pertanyaan terkait apa yang telah dipelajari serta memberikan kesan dan impresi yang baik terhadap seluruh rangkaian kegiatan ini. 
Setelah memberikan materi mengenai competency based interview (CBI) maka kelompok tetap menjaga hubungan baik dengan komunitas. Kelompok membuat modul untuk komunitas agar pengetahuan mengenai competency based interview (CBI) tetap ada pada komunitas. Modul berisi definisi, tahapan competency based interview (CBI), metode questioning yang ada pada behavioral evidence interview (BEI), teknik pertanyaan seperti pertanyaan yang seharusnya ditanyakan dan pertanyaan yang seharusnya tidak ditanyakan. Selanjutnya terdapat rules of evidence yang berisi cara menyaring jawaban relawan untuk dinilai saat leveling, sasaran komponen sesuai yang dibutuhkan oleh komunitas beserta levelingnya, pertanyaan untuk calon relawan beserta probing nya.

Setelah memberikan modul, kelompok juga tetap menjalin komunikasi dengan komunitas, baik dengan managing director dan juga dengan kepala divisi dan staff. Kelompok berencana akan mengulang kembali materi dengan singkat dan melakukan diskusi sebelum managing director melakukan pelatihan kepada staf. Hal ini dilakukan agar materi yang disampaikan bisa diingat kembali, mengingat jarak waktu antara managing director menerima materi dan memberikan materi cukup jauh yaitu kurang lebih 6 bulan.

Tujuan akhir dari intervensi ini adalah meningkatnya persentase jumlah relawan yang berpartisipasi aktif selama berlangsungnya program. Selain itu, setiap relawan juga mampu untuk menyelesaikan job-description divisinya masing-masing sehingga pada akhirnya pekerjaan pada masing masing divisi dapat selesai pada tengat waktu yang sudah ditentukan.

\section{HASIL DAN DISKUSI/RESULT AND DISCUSSION}

Berdasarkan intervensi yang telah dilakukan kepada komunitas, kelompok menganggap bahwa rangkaian kegiatan yang dilakukan berhasil. Hal tersebut didukung dengan hasil checklist dari seluruh indikator keberhasilan. Kelompok memutuskan untuk menyasar rangkaian kegiatan pada aspek kognitif dan aspek perilaku sesuai tahapan perkembangan pada taksonomi Bloom. Aspek kognitif yang diharapkan dari komunitas adalah mampu mengetahui, memahami, menerapkan, dan menganalisis. Komunitas diharapkan mampu memberikan edukasi kepada para kepala divisi dalam menerapkan competency-based interview. Aspek perilaku juga disasar kelompok dalam pemberian intervensi dengan harapan komunitas mampu menggambarkan, mempersiapkan, mengaplikasikan, serta membiasakan metode wawancara dengan teknik tersebut.

Berdasarkan indikator keberhasilan pada aspek kognitif, komunitas berhasil pada indikatorindikator seperti mendefinisikan kompetensi yang dibutuhkan yaitu kesadaran berorganisasi, komunikasi, berpikir konseptual, dan komitmen terhadap organisasi; mampu menyebutkan teknik-teknik wawancara yang akan digunakan; mampu menjelaskan cara penyampaian competency-based interview (CBI) yang benar; mampu menjelaskan cara melakukan leveling penilaian; mampu menerapkan pertanyaan yang bersifat terbuka; mampu memberikan pertanyaan tambahan terkait dengan jawaban dari calon relawan (probing); mampu menyesuaikan pengalaman calon relawan pada leveling kompetensi mampu menghasilkan keputusan terkait penerimaan relawan; mampu membandingkan proses competency-based interview dengan proses rekrutmen sebelumnya; serta mampu menganalisa proses wawancara orang lain. Untuk indikator keberhasilan pada aspek perilaku, komunitas berhasil pada indikator mampu menggambarkan wawancara dengan teknik competency-based interview; mampu mengawali wawancara sesuai prosedur (pengenalan diri, menjelaskan tujuan wawancara, memberikan instruksi); mampu menirukan teknik-teknik wawancara competency-based interview; bersedia mencoba melakukan wawancara dengan teknik competency-based interview; mampu mempraktekkan teknik wawancara competency-based interview secara keseluruhan (sesuai prosedur wawancara, mampu melakukan probing, competency-based interview); mampu mengendalikan hal-hal tidak terduga 
selama proses wawancara (calon relawan kurang memahami pertanyaan, jawaban calon relawan lebih dari waktu yang ditentukan, jawaban calon relawan kurang menyasar pada kompetensi, perilaku calon relawan kurang sesuai, dll); serta mampu memperbaiki perkataan atau perilaku wawancara dirinya sendiri.

Selain dari indikator keberhasilan, observasi kelompok juga mendukung hasil kegiatan. Kelompok melihat bahwa pihak komunitas memahami penjelasan dari tanya jawab yang interaktif dan diskusi pada setiap sesi, bahkan mengoreksi dan memastikan pemahaman mereka sesuai dengan penjelasan. Mereka juga menanyakan berbagai hal terkait CBI yang tidak termasuk dalam presentasi serta mengajak diskusi terkait kasus-kasus tertentu yang mereka pernah alami pada tahap rekrutmen. Perwakilan dari komunitas juga bersikap atentif dan sangat mendalami peran mereka saat melakukan roleplay. Mereka juga mendengarkan dan mempertimbangkan feedback yang diberikan seusai roleplay. Pada akhir sesi, kedua perwakilan komunitas juga memberikan respon yang positif dan mendukung. Hal tersebut dibuktikan dengan adanya pernyataan dari Managing Director komunitas untuk mendiskusikan dan menindaklanjuti intervensi pada rekrutmen relawan pada tahun berikutnya.

Leveling untuk kompetensi pada setiap divisi diperlukan, agar calon relawan yang menjadi bagian dari SabangMerauke ahli pada divisi dimana calon relawan bergabung. Namun leveling kompetensi setiap divisi tidak dibuat oleh kelompok. Karena berdasarkan wawancara dengan managing director, SabangMerauke menerima calon relawan yang ingin belajar. Sehingga tidak masalah tidak ada pengalaman pada divisi tersebut namun memiliki keinginan untuk belajar mengenai divisi tersebut. Karena jika kelompok membuat kompetensi pada setiap divisi yang berisi tentang kemampuan pada divisi tertentu, maka calon relawan yang tidak memiliki pengalaman dibidang tersebut nilainya akan cenderung rendah dan tidak diterima menjadi bagian dari SabangMerauke.

Meskipun rangkaian kegiatan kelompok dianggap berhasil, terdapat beberapa kendala yang kelompok hadapi selama menjalani proses. Pertama, kelompok sulit menyesuaikan jadwal untuk melakukan intervensi dengan komunitas sehingga intervensi hanya dapat diberikan satu kali. Hal tersebut dikarenakan komunitas sedang memiliki jadwal yang cukup padat, dan kebetulan bersamaan pula dengan jangka waktu yang diberikan untuk melakukan intervensi. Kelompok juga tidak dapat memastikan apakah intervensi yang diberikan kepada komunitas akan diterapkan secara nyata. Intervensi yang diberikan terkait rekrutmen relawan hanya berlangsung selama satu kali setiap tahunnya. Sedangkan, kondisi komunitas saat ini telah melewati tahap tersebut. Kendala tersebut menyadarkan kelompok bahwa intervensi yang akan diterapkan komunitas baru dapat dipastikan tahun depan, menyesuaikan dengan timeline komunitas.

\section{SIMPULAN DAN SARAN/CONCLUSION AND RECOMMENDATION}

Kesimpulan dari rangkaian intervensi yang diberikan adalah pemberian training for trainers kepada Komunitas SabangMerauke sudah tepat dan menyasar pada apa yang mereka butuhkan. Hal ini didasari atas penilaian kelompok terhadap checklist indikator keberhasilan yang telah dirancang sebelum training for trainers berlangsung. Selain dari indikator keberhasilan, terdapat bukti nyata yang menunjukkan keberhasilan intervensi ini yaitu respon dan keaktifan dari kedua responden yang hadir. Selain mendengarkan, mereka juga melontarkan beberapa pertanyaan serta secara aktif mengkonfirmasi pengetahuan mereka kepada kelompok dengan berdiskusi. Pihak komunitas juga meminta kelompok untuk dapat menindaklanjuti proses rekrutmen komunitas di tahun berikutnya. Walaupun dari segi intervensi tergolong berhasil, namun terdapat beberapa kendala dialami oleh kelompok seperti intervensi yang hanya dapat dilakukan satu kali karena 
mengikuti jadwal dari pengurus komunitas. Intervensi ini juga tidak dapat diimplementasikan secara langsung oleh pihak komunitas karena tahap rekrutmen pada tahun ini sudah tutup dan akan diterapkan pada tahun selanjutnya berdasarkan penuturan dari General Manager komunitas.

Terdapat beberapa hal yang dapat ditingkatkan dari training yang diberikan kepada pengurus Komunitas SabangMerauke. Dari segi modul, isi konten sudah ringkas, jelas, dan menyertakan contoh. Namun, ada beberapa kesalahan penyusunan modul sehingga pada bagian "Do" and "Don't," tidak terpisahkan dan dapat membuat pembaca merasa bingung. Selain itu, pada bagian leveling, akan lebih baik jika pada setiap penjelasan penilaian dibuat lebih rinci dan terukur sehingga interviewer lebih tepat dan akurat dalam me-leveling jawaban interviewee.

Kedua, dari pihak fasilitator, kedepannya lebih baik jika menjelaskan dengan penuh percaya diri dan tidak terbata-bata ketika menjelaskan. Hal ini dapat berpengaruh pada kesan dan respon responden. Mereka akan meremehkan fasilitator yang menjelaskan dan tidak menganggap training ini terpercaya. Untuk itu, fasilitator juga harus lebih mempersiapkan diri sebelum presentasi dan sebisa mungkin melakukan pilot test sebelum memberikan training langsung ke target sasaran.

Saran yang ketiga adalah membuat janji dengan pihak komunitas dari jauh-jauh hari, kurang lebih dua bulan sebelum. Pemilihan tanggal pelaksanaan akan sulit dilakukan khususnya pada komunitas seperti SabangMerauke yang pengurus dan panitianya sebagian besar merupakan relawan, berdomisili di berbagai daerah di Indonesia, merupakan pekerja tetap di instansi lainnya, dan tidak memiliki office yang tetap. Dengan melakukan penetapan jadwal dari jangka waktu yang lama, maka para pengurus maupun relawan dapat meluangkan waktunya pada hari yang sudah ditentukan.

Bersinggungan dengan saran sebelumnya, keterlibatan komunitas di dalam intervensi ini penting terutama petinggi-petinggi di komunitas seperti rekan BPH. Kehadiran mereka menjadi penting karena merekalah yang nantinya akan memberikan training ini kepada bawahannya. Semakin banyak yang hadir, maka semakin banyak diskusi dan pendapat yang dapat muncul sehingga baik dari modul, panduan wawancara hingga leveling dapat direvisi dan ditingkatkan hingga menghasilkan hasil yang optimal. Selain itu, dengan banyaknya orang yang terlibat, maka lebih banyak orang yang memiliki pengetahuan yang serupa mengenai CBI sehingga ketika mereka ingin melakukan training for trainers kepada bawahan mereka, akan lada lebih banyak trainers yang dapat melatih.

Jika intervensi akan dilakukan kembali, baik kepada Komunitas SabangMerauke maupun komunitas lainnya yang serupa (seperti memiliki periode waktu kegiatan dalam satu tahun), maka intervensi akan lebih tepat jika mengikuti agenda dari komunitas itu sendiri. Hal tersebut dilakukan agar kelompok lebih mudah dalam melakukan monitoring serta evaluasi dari intervensi yang diberikan. Kelompok melakukan intervensi mengenai seleksi relawan saat komunitas sedang sibuk menjalankan programnya. Dengan kasus ini, kelompok mengalami beberapa kendala. Pertama, hal tersebut membuat pihak kelompok dan komunitas sulit mencari jadwal untuk intervensi. Kedua, intervensi yang diberikan belum bisa dilaksanakan karena jadwal seleksi relawan akan dilaksanakan pada bulan Januari setiap tahunnya. Oleh karena kedua hal tersebut, intervensi yang diberikan oleh kelompok tidak bisa langsung dilaksanakan secepatnya oleh komunitas karena komunitas sudah memiliki jadwal kegiatan atau timeline yang tetap. Kelompok menyarankan agar intervensi ini idealnya dilakukan pada bulan November atau Desember, karena pada bulan Januari akan dilaksanakan seleksi relawan SabangMerauke. Periode waktu intervensi tersebut ditetapkan atas pertimbangan keefektifan materi yang berpengaruh pada cara pengurus 
melakukan wawancara kepada interviewee. Jika intervensi dilaksanakan jauh sebelum proses rekrutmen yang akan dilakukan komunitas, terdapat kemungkinan pengurus-pengurus yang mengikuti training intervensi akan lupa dengan materi yang diberikan. Namun, pada kasus ini, kelompok juga harus menyesuaikan dengan jadwal mata kuliah Psikologi Pendidikan Berbasis Komunitas sehingga tidak memungkinkan untuk melakukan intervensi pada bulan Desember atau Januari.

\section{Ucapan Terima Kasih/Acknowledgement}

Kami ingin berterima kasih yang sebesar-besarnya kepada Kak Reynold Hamdani selaku General Manager Komunitas Sabang Merauke dan Kak Wildan Mahendra, selaku Engagement Manager Komunitas SabangMerauke yang telah meluangkan waktunya untuk hadir dan mengikuti training mengenai CBI dari awal hingga akhir dengan sangat atentif. Tak lupa kami ucapkan terima kasih kepada JSCHive by Co-hive yang telah menyediakan ruangan yang nyaman dan fasilitas yang memadai, Wieky Fie Desyana dan Imelda Rahajeng Amarta sebagai peran pembantu yang membantu kelancaran sesi roleplay serta memainkan peran mereka dengan baik, juga pihakpihak lain yang telah mendukung rangkaian pelaksanaan kegiatan.

\section{REFERENSI}

Handoko, T. Hani. (2008). Manajemen Personalia Dan Sumber Daya Manusia. Edisi Kedua. Yogyakarta: BPFE Yogyakarta.

Kessler, R. (2006). Competency-Based Interview. Franklin Lakes: The Career Press, Inc., 255 p

Potale, B. R., Lengkong, V., \& Moniharapon, S. (2016). Pengaruh proses rekrutmen dan seleksi terhadap kinerja karyawan pada PT. Bank Sulutgo. Jurnal Berkala Ilmiah Efisiensi, 16 (4), 453-464.

Siahaan, J.T.H. (2019). Februari 15 2019. Komoditifikasi Intoleransi. Kompas.com. Diambil dari https://nasional.kompas.com/read/2019/02/15/07110051/komoditifikasi intoleransi?page $=$ all

Snyder, M., Omoto, A. M. (2008). Volunteerism: Social issues perspectives and social policy implications. Social Issues and Policy Review, 2, 1-36. 